\title{
クーロメトリー検出液体クロマトグラフィーによるケイ酸, リン酸及びゲルマニウム酸イオンの定量*
}

\author{
高用 芳矩**®，武藤 義一***
}

(1978 年 5 月 4 日受理)

\begin{abstract}
クーロメトリー検出液体クロマトグラフィーによるケイ酸, リン酸及びゲルマニウム酸イオンの分析 法を検討した.

分離カラムには強塩基性陰イオン交換樹脂を用いたが，ケイ酸とゲルマニウム酸イオンの分離には $0.4 \mathrm{M}$ 水酸化ナトリウムを, 叉, ケイ酸とリン酸イオンには $0.4 \mathrm{M}$ 水酸化ナトリウム $-0.02 \mathrm{M}$ 硫酸ナ トリウムを溶離液とするのが良い。一方, 検出は, 作用電極電位を $0.10 \mathrm{~V} v s$. フェリシフンーフェロシ アンに設定して行ったが，モリブデン酸アンモニウム $\left\{\left(\mathrm{NH}_{4}\right)_{6} \mathrm{Mo}_{7} \mathrm{O}_{24}\right\}$ の濃度が約 $0.8 \%$ のときは, 硫酸濃度 $(0.4 \pm 0.1) \mathrm{N}$ ，反応時間 5 分が良いことが分かった。この条件下での検出下限は $0.2 \mathrm{ppm}(\mathrm{Si}$ 及び P として) で，リン酸イオンは（1２50)ppm P，ヶイ酸イオンは（1〜50) ppm Si まで直線性の良

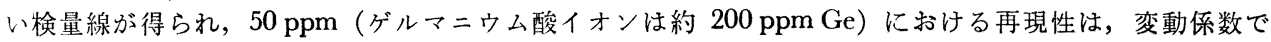
2\%以内であった.
\end{abstract}

\section{1 緒萻}

微量のケイ酸及びリン酸イオンは“モリブデン青”反 応を応用した比色法で検出定量される1)。これは, 周知 のように，ケイ酸及びリン酸イオンとモリブデン酸イオ ンとが反応して得られるへテロポリ酸を，亚硫酸ナトリ ウムや塩化第一スズなどで還元して生成する“モリブデ ン青”の（610〜830) nm における吸光度を測定する方 法である，この分析操作はそのまま自動化された2)が， 還元剂, 干渉成分に詨するマスキング剂など多くの試薬 を混合するなど煩雑である。一方，へテロポリ酸を電気 化学的に還元する方法は, いったん有機溶媒に抽出した 後, ポーラログラフィーにより定量する方法に応用され ている3(4). これら睘元反応については, Strickland5)

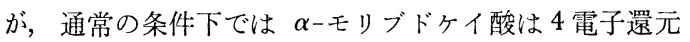
により緑青色の $\alpha$-silicomolybdous acid を生成し, 更 に 1 電子還元により青色の $\alpha$-hyposilicomolybdous acid を生成することを述べている，モリブドリン酸も 電気化学的に還元されることが知られている ${ }^{6)}$. これ

* 定電位クーロメトリーの自動記録液体クロマトグラ フィーへの応用(第 9 報). 前報は高田芳矩, 有川 喜次郎，武藤義一：本誌，26，407 (1977)

** 株式会社日立製作所日立研究所 : 茨城県日立市久慈 町大﨎 4026

*** 東京大学生産技術研究所：東京都港区六本木7-22-1
を，酸の濃度がある程度以上であればモりブデン酸それ 自体は還元されないで，へテロポリ酸のみ選択的に還元 されることと合わせて考えると，へテロポリ酸を水溶液 中で定電位クーロメトリーにより定量可能であると推定 される，そこで，同様にへテロポリ酸を生成するゲルマ ニウム酸イオンをも加え，これら 3 成分をイオン交換分 離した後に定電位クーロメトリーで検出するクーロメト リ一検出液体クロマトグラフィーについて検討した。そ の結果，この方法がこれらモリブデン酸とへテロポリ酸 を形成する成分の $\mathrm{ppm}$ レベルの自動分析に適すること が明らかになったので報告する。

\section{2 実験}

\section{$2 \cdot 1$ 装}

実験装置の流路四を Fig. 1 に示した.ここに示した 液体クロマトグラフは手製で，溶離液送液ボンプには高 橋技研製ミニマイクロポンプ $\mathrm{S}-2$ 型を用い，分離カラ ムの前に試料容量 $0.5 \mathrm{ml}$ のサンプリングバルブを設け ている. 分離カラムは, 内径 $9 \mathrm{~mm}$, 長さ $100 \mathrm{~mm}$ の恒 温水ジャケット付きガラスカラムに, 日立カスタムイオ ン交換樹脂 $¥ 2630$ (強塩基性陰イオン交換樹脂)を $2 \mathrm{~N}$ 水 酸化ナトリウムで洗浄後高さ $80 \mathrm{~mm}$ に充てえしたもの である. カラム流出液は, 東京理化器械製マイクロチュ ーブポンプ，MP-1 型により送られるモリブデン酸アン モニウム溶液及び硫酸と混合された後, 恒温そう(水浴) に浸せきした反応コイル（内径 $1 \mathrm{~mm}$ テフロンチュー ブ）を通過させる. その後，日立製 $630 \mathrm{C}$ 形クーロメト 


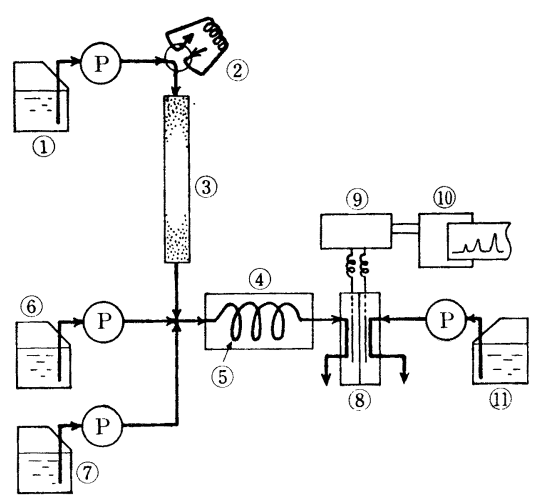

Fig. 1 Schematic diagram of apparatus

(1) Eluent; (2) Sampling valve; (3) Separation column; (4) Water bath; (5) Reaction coil; (6) $5 \%\left(\mathrm{NH}_{4}\right)_{6}$ $\mathrm{Mo}_{7} \mathrm{O}_{24}$; (7) $\mathrm{H}_{2} \mathrm{SO}_{4}$; (8) Electrolytic cell; (9) Potentiostat; (10) Recorder; (11) $0.1 \mathrm{M} \mathrm{K}_{3} \mathrm{Fe}(\mathrm{CN})_{6}-0.1 \mathrm{M}$ $\mathrm{K}_{4} \mathrm{Fe}(\mathrm{CN})_{6}-0.1 \mathrm{M} \mathrm{KNO}_{3}-1 \mathrm{M} \mathrm{NH}_{4} \mathrm{OH}$

リックモニターに至る.クーロメトリックモニターの電 解セルのイオン交換膜は, 通常は 1 枚であるが, 硫酸酸 性溶液中では寿命が短いので，ここでは 2 枚重ね合わせ て使用した。

\section{2 試 薬}

ケイ酸イオンの標準試料は関東化学製原子吸光用標準 溶液を実験の都度希釈して, 一方，リン酸イオン試料 は，リン酸ナトリウムを水に溶解して調製した。 ゲルマ ニウム酸イオンの試料は金属片を王水及び次亜塩素酸ナ トリウムを添加して加熱溶解したが，完全には溶解でき ず，正確な濃度のものは得られなかった。これら標準試 料はすベてポリエチレン製メスフラスコを使用して調製 した.

モリブデン酸アンモニウム溶液は，モリブデン酸アン モニウム四水和物を $53 \mathrm{~g}$ 及び濃アンモニア水 $4 \mathrm{ml}$ を約 $500 \mathrm{ml}$ の水に入れ，(60〜70) ${ }^{\circ} \mathrm{G}$ に加温（10 分以内）乙 て溶解した後水を加えて 11 としたもの（5\%モリブデ ン酸アンモニウム溶液）と，これに硫酸を加えて $2.5 \%$ モリブデン酸アンモニウム $-1.75 \mathrm{~N}$ 硫酸酸性溶液にした ものの 2 種類を使用した.

フェリ・フェロ対極液は, フェリシアン化カリウム $42 \mathrm{~g}$ ，フェロシアン化カリウム $33 \mathrm{~g}$, 硝酸カリウム 10 $\mathrm{g}$ を水に溶解し, 更に濃アンモニア水 $70 \mathrm{ml}$ を加え 11 にしたものである。

その他の試薬はすべて市販特級品をそのまま使用して 調製した。

\section{3 方 法}

まず，溶離液（水酸化ナトリウム一硫酸ナトリウム系） を $1.5 \mathrm{ml} / \mathrm{min}$ で流し，カラム流出液に硫酸 $\{(2 \sim 6) \mathrm{N}\}$ を $0.42 \mathrm{ml} / \mathrm{min}$ 及び $5 \%$ モリブデン酸アンモニウム溶
液を $0.36 \mathrm{ml} / \mathrm{min}$ で加光た。一方, 反心゙コルは長さ (0.5〜26) $\mathrm{m}$ に变えて反応時間を調節し，间時に反応温 度を（17〜 70 $)^{\circ} \mathrm{C}$ の範囲で变化させてケイ酸，リン酸及 びダルマニウム酸イオン闹時検出に適する条件を求る゙ た.なお，検出電位は $0.10 \mathrm{~V} v s$. フェリシアンーフェロ シアンに設定した.

次に，溶離液の組成を種々変えて得られるクロマトグ ラムから分離に適する浴離条件を決疋した.

\section{3 結果及び考祭}

\section{1 検出感度に及ぼす硫酸濃度の影響}

試料を添加しない状態で電解セル流入液の電流電位曲 線を測定したが，0.10Vより卑の電位でバックグラウン ド電流が急激に高くなりはじめることが分かった. そこ で，作用電極電位は $0.10 \mathrm{~V}$ に設定した. この電位で硫 酸濃度を変え, クロマトグラムを描き, 各成分のピーク 面積を測定して検出感度を比較した. その結果は Fig. 2 に示した。硫酸濃度は, 溶離液及び硫酸などの送液量か ら算出してプロットしているが，ゲルマニウム酸イオン は $0.3 \mathrm{~N}$ ，リン酸イオンは $0.5 \mathrm{~N}$ 以上でほぼ一定の検出 感度を示している.ところが，ケイ酸イオンは硫酸濃度 の影響を大きく受け，0.4 N 前後で感度が最大になって いる，最大付近での硫酸とモりブデン酸アンモニウムの 濃度比 $\left(\left[\mathrm{H}^{+}\right] /\left[\mathrm{MoO}_{3}\right]\right)$ は約 9 で, これは比色法の場合 の 5.02)より大きい. 又, 硫酸濃度が $0.65 \mathrm{~N}$ 以上でもり ン酸の $1 / 5$ 以上の感度を示しているが，これ斗此色法で は 1/500 以下で女るわので，その様子はかなり異なると いえる。

バックグラウンド電流は $0.1 \mathrm{~N} て ゙ ~ 0.34 \mathrm{~mA}$ で,これ は硫酸の濃度増加とともに漸減したが，0.5Nでも 0.32 $\mathrm{mA}$ とその変化は小さかった.

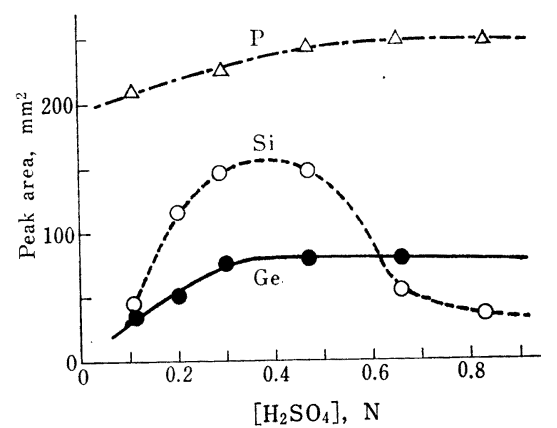

Fig. 2 Effect of $\mathrm{H}_{2} \mathrm{SO}_{4}$ concentration

$\mathrm{P}: 50 \mathrm{ppm} ; \mathrm{Si}: 50 \mathrm{ppm} ; \mathrm{Ge}: c a .40 \mathrm{ppm} ; \quad\left(\mathrm{NH}_{4}\right)_{6}-$ $\mathrm{Mo}_{7} \mathrm{O}_{24}: 0.79 \%\left(\left[\mathrm{MoO}_{3}\right]: 0.047 \mathrm{M}\right) ; \quad$ Reaction time : $6 \mathrm{~min}$; Reaction temp. : $20^{\circ} \mathrm{C}$ 


\section{2 反応時間}

カラム流出液にモリブデン酸アンモニウム溶液と, 硫 酸を $0.34 \mathrm{~N}$ になるように添加し, 反応時間をかえて各 成分の検出感度を測定した。その結果を Fig. 3 に示し た.リン酸イオンは 2 分以上でほぼ一定の感度を示すの に対し，ケイ酸イオンは反心時間とともに上昇してい る.これは, ケイ酸イオンの単量体は 75 秒で反心を終 了するが，2 量体は反応に約 10 分を要する8)ことから 考えると, 分離カラムから流出したケイ酸イオンが一部 重合し多量体を生成していることを意味するとも考兄ら れるが明らかでない，一方，ゲルマニウム酸イオンは約 40 秒で最大になり，それ以上では逆に低下している. いずれにせよ，あまり反応コイルを長くし過ぎると，カ ラムで分離した成分の再混合による分離能の低下をもた らし，そのうえ分析時間を長くする，それゆ光，以降反 応時間は 5 分（反忘コイル長さ $15 \mathrm{~m}$ ) とした.

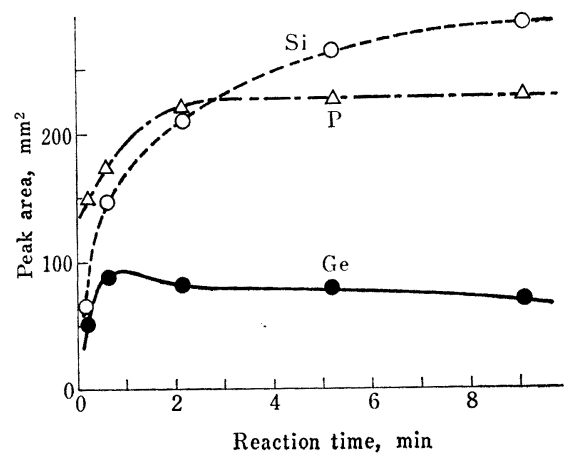

Fig. 3 Effect of reaction time

$\mathrm{Si}$ : $100 \mathrm{ppm}$; Reaction temp. : $17^{\circ} \mathrm{C}$; Other conditions same as in Fig. 2

\section{3 反応温度の影響}

ゲルマニウム酸イオンは反応時間を増すことで感度は わずかずつ低下したが，モリブドゲルマニウム酸が分解 したためと仮定すると，反応温度を上げると感度低下の 頃向は一層顕著になると考えられる，そこで，反応温度 を変えてそれぞれの感度を求めた. その結果は Fig. 4 に示した. 予想に反してゲルマニウム酸イオンは温度上 昇とともにわずかではあるが感度は上昇している.

,ケイ酸イオンの場合は，温度とともに感度は上昇し， カラム流出液中に多量体が含まれていることを裏付けて いると考えられる．しかし，モリブドケイ酸は更に温度 を上げ $60^{\circ} \mathrm{C}$ 以上になると分解しはじめると考えられ る.リン酸イオンの場合には, $30^{\circ} \mathrm{C}$ 以上で感度が低下 する.

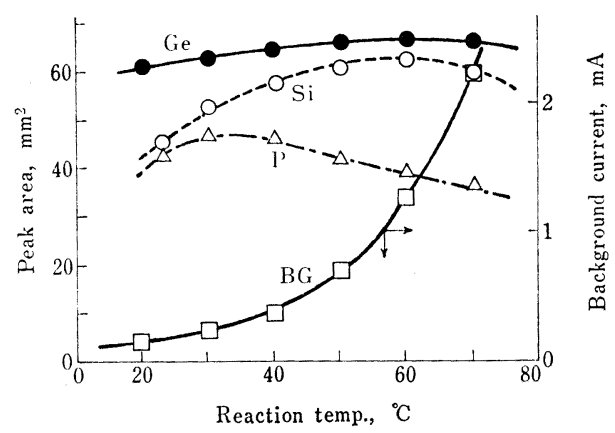

Fig. 4 Effect of reaction temperature

$\mathrm{Si}: 20 \mathrm{ppm}$; P : $10 \mathrm{ppm}$; Reaction time : $5 \mathrm{~min}$; Other condtions same as in Fig. 2

反応温度のバックグラウンドに及ぼす影響についても Fig. 4 に示したが, 特に $40^{\circ} \mathrm{C}$ 以上でバックグラゥン ドが著しく上昇している．これは，モリブデン酸が加熱 することで電気化学的により還元されやすい構造に変わ ると考えられた，それゆ光，反応温度は $40^{\circ} \mathrm{G}$ 以下が良 いであろら。

\section{4 溶離条件の検討}

溶離液に，0.4 M 水酸化ナトリウムに硫酸ナトリウム を種々添加したものを用いて，強塩基性陰イオン交換カ ラムに注入されたケイ酸，リン酸及びゲルマニウム酸 イオンの 3 成分混合試料の分離を行った. その結果は Fig. 5 に示した. リン酸イオンを他のイオンから分離

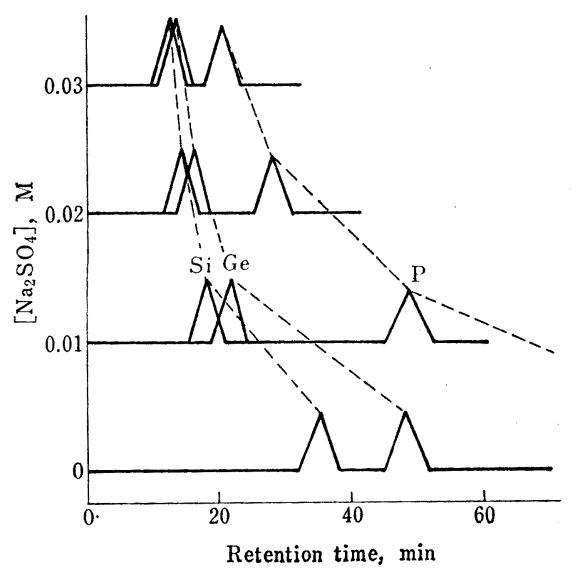

Fig. 5 Effect of $\mathrm{Na}_{2} \mathrm{SO}_{4}$ concentration in eluent on retention time

Column : Hitachi Custom Ion-Exchange Resin \#2630, $9 \mathrm{~mm}$ i. d. $\times 70 \mathrm{~mm}$, room temp.; Eluent : $0.4 \mathrm{M}$ $\mathrm{NaOH}-\mathrm{Na}_{2} \mathrm{SO}_{4} ;$ Flow rate $: 1.5 \mathrm{ml} / \mathrm{min}$ 
するには，液中の硫酸ナトリウム濃度を $0.02 \mathrm{M}$ 程度に すれば良いことが分かる。このクロマトグラムの1例は Fig. 6 に示した. しかし,ケイ酸とゲルマニウム酸イオ ンの分離には硫酸イオンが溶離液中に含まれることは好 ましくなく，Fig. 7 にクロマトグラムの例を示すよう に, むしろ水酸化ナトリウムのみの溶離液で溶離するの が良いことが分かる.

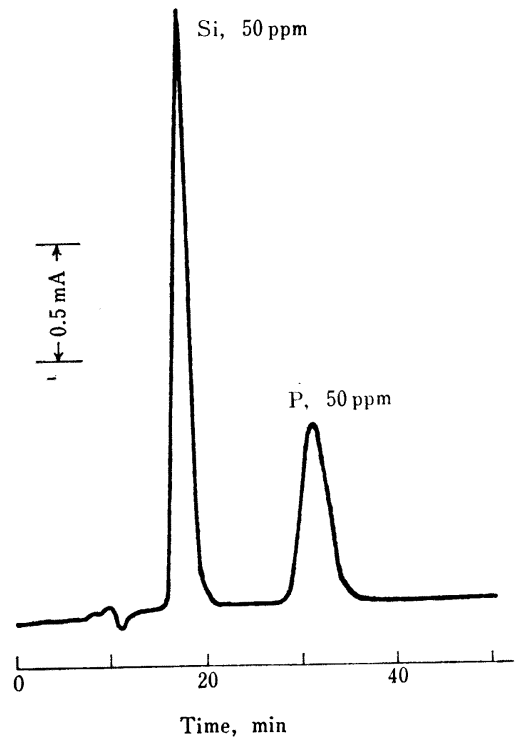

Fig. 6 Typical chromatogram for silicate and phosphate ions

Column : Hitachi Custom Ion-Exchange Resin \#2630, $9 \mathrm{~mm}$ i. d. $\times 80 \mathrm{~mm}, 40^{\circ} \mathrm{C}$; Eluent : $0.4 \mathrm{M} \mathrm{NaOH}$ $0.02 \mathrm{M} \mathrm{Na}_{2} \mathrm{SO}_{4}$; Flow rate : $1.5 \mathrm{ml} / \mathrm{min}$; Reagent : $1.75 \mathrm{~N} \mathrm{H}_{2} \mathrm{SO}_{4}-2.5 \%\left(\mathrm{NH}_{4}\right)_{6} \mathrm{Mo}_{7} \mathrm{O}_{24} ;$ Flow rate: $0.75 \mathrm{ml} / \mathrm{min}$; Detection potential $: 0.10 \mathrm{~V}$ vs. ferriferrocyanide

\section{5 直線性}

ケイ酸及びリン酸イオンについて, 濃度範囲 $(1 \sim 250)$ $\mathrm{ppm}(\mathrm{Si}$ 及び $\mathrm{P}$ として）の各試料を $0.5 \mathrm{ml}$ ずつ添加 し，得られたクロマトグラムから各成分のピーク面積を 測定した. Fig. 8 にそれぞれの検量線を示した・リン酸 イオンについては良い直線性を示しているが，ケイ酸イ オンの場合は $50 \mathrm{ppm}$ Si 以上で感度が低下し，曲線にな る.これは，モリブデン酸との反応が遅く，高濃度にな るほど重合して未反応物の 割合が増すためと考えられ た. ここでへテロポリ酸は 4 電子還元を受けると仮定し て検量線の直線部に拈汀る電解効率を算出したが，リン 酸イオンで約 $85 \%$ ，ケイ酸イオンは約 $55 \%$ であった. ゲルマニウム酸イオンについては正確な濃度の試料が得

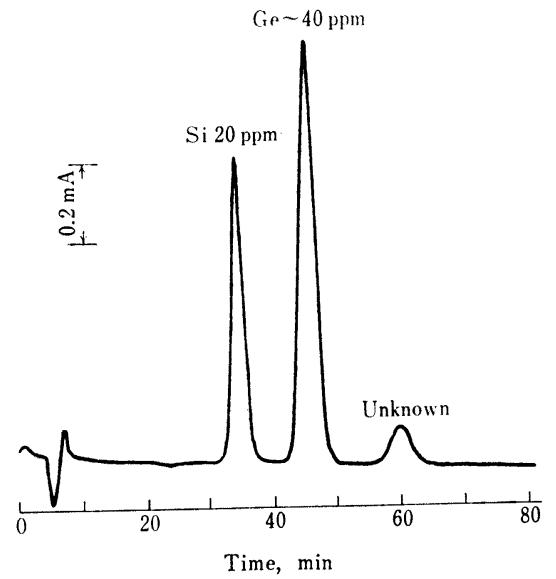

Fig. 7 Chromatogram for silicate and germanate ions

Eluent : $0.4 \mathrm{M} \mathrm{NaOH}$; Other conditions same as in Fig. 6

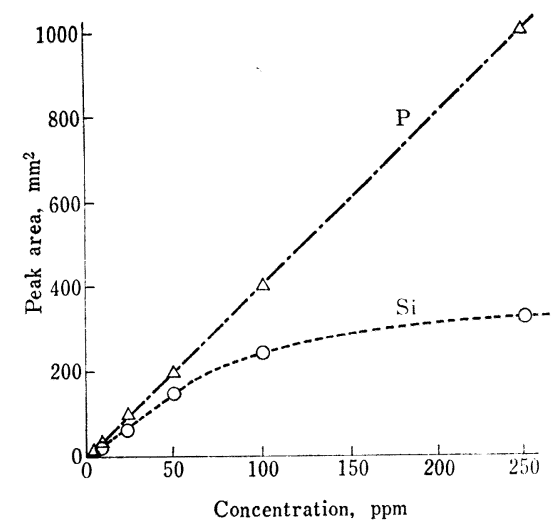

Fig. 8 Calibration curves

$\left(\mathrm{NH}_{4}\right)_{6} \mathrm{Mo}_{7} \mathrm{O}_{24}: 0.79 \% ; \quad\left[\mathrm{H}_{2} \mathrm{SO}_{4}\right]: 0.34 \mathrm{~N} ; \mathrm{Re}-$ action time : $6 \mathrm{~min}$; Reaction temp. : $18^{\circ} \mathrm{C}$

られなかったので測定してはいない。なお,検出下限 (濃 度限界) はリン酸イオン, ケイ酸イオンとも約 $0.2 \mathrm{ppm}$ であった。

\section{6 再現性}

ケイ酸とリン酸イオンは $50 \mathrm{ppm}(\mathrm{Si}$ 及び $\mathrm{P}$ として), ゲルマニウム酸イオンは約 $200 \mathrm{ppm} \mathrm{Ge}$ の標準試料を用 いて再現性を検討した，溶離液の組成を変えるとその後 約 8 時間は再現性がやや悪くなる. しかし，カラムが平 衡に達した場合には, Table 1 に示したように再現性は, いずれのイオンについても変動係数で $2 \%$ 以内であっ 
Table 1 Reproducibility

\begin{tabular}{lrc}
\hline \multicolumn{1}{c}{ Ion } & $\begin{array}{c}\text { Concentration } \\
(\mathrm{ppm} \text { as } \mathrm{Si}, \mathrm{P} \text { and } \mathrm{Ge})\end{array}$ & $\begin{array}{c}\text { Coefficient of } \\
\text { variation }(\%)\end{array}$ \\
\hline Silicate ion & 50 & 0.8 \\
Phosphate ion & 50 & 1.7 \\
Germanate ion & ca. 200 & 1.7 \\
\hline
\end{tabular}

た. ばらつきの最大の原因は, 各送液ポンプの流量比の 変動に伴ら感度変化と考えられた.

\section{7 妨害イオン}

妨害イオンには 2 種類考えられた. 一つは先の条件下 で検出され，しかも目的成分とは分離されない成分，も ら一つは溶離液又は反応液中で沈殿を生成する成分であ る. 前者の例としてへテロポリ酸形成の可能性のある七 素 $(\mathrm{V})$ とアンチモン $(\mathrm{V})$, それに直接還元されて検出さ れるクロム酸の各イオンを取り上げた。 クロム酸イオン はリン酸イオンのはるか後に溶出し, 又他の 2 成分は検 出されず，いずれも妨害しなかった，一方，後者の例と してマグネシウム, カルシウム, 銅(II), 㶾鉛, マンガ ン(II) イオンを取り上げた。すなおち, 各々金属イオン を $1000 \mathrm{ppm}$ 含主試料に $2 \mathrm{M}$ 水酸化ナトリウムを添加し $0.1 \mathrm{M}$ 水酸化ナトリウム試料溶液とし, 沪過後沪液を力 ラムに添加して分離検出した， その結果，マグネシウム 及びカルシウムイオンが共存するとケイ酸及びリン酸イ オンはともに大部分が共沈して検出されなくなる. 又, 上記重金属イオンを含も場合はリン酸イオンで約 $90 \%$, ケイ酸イオンでは約 $40 \%$ が検出され，回収率が低下す ることが明らかになった。すなわち，アルカリ土類金属 や重金属イオンなどを含导試料は水素形あるいはナトリ ウム形陽イオン交換樹脂を通すなどの試料前処理をする か，又は，酸性溶離液を用いて分離するなど工夫を必要 とすることが分かった.

\section{8 応用例}

水道水をなんらの処理もせず，そのまま $0.5 \mathrm{ml}$ 添加 してクロマトグラムを描いた. その結果は Fig. 9 に示 した. ピーク面積の測定から水道水中には $8 \mathrm{ppm} \mathrm{Si} の$ ケイ酸イオンが含まれていることが分かった，又，リン 堲イオンは検出されなかった $(\langle 0.2 \mathrm{ppm} \mathrm{P})$. 溶解シリ カのみ検出されているが，いずれにせよ，数 $\mathrm{ppm}$ 程度 含まれるこれらの成分の分析には便利な方法であるとい えよう。

$$
4 \text { 結 言 }
$$

以上，ケイ酸，リン酸及びゲルマニウム酸イオンをイ

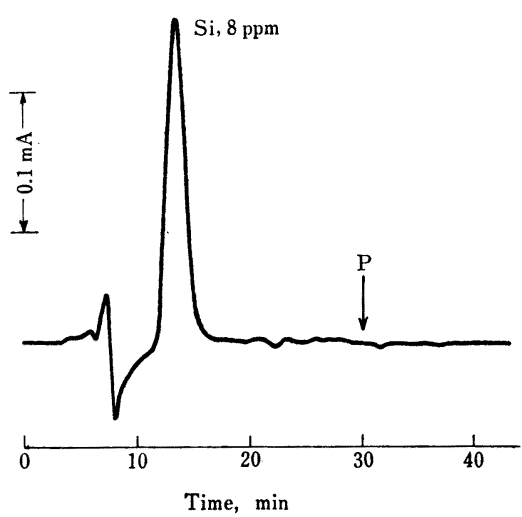

Fig. 9 Analysis of tap water

Sample : $0.5 \mathrm{ml}$; Conditions same as in Fig. 6

オン交換クロマトグラフィーにより分離し，モリブドへ テロポリ酸を生成させた後, それらの電気化学反応を応 用して検出する方法が十分可能であることを述べた．本 法によればこれまで煩雑とされていたケイ酸，リン酸及 びゲルマニウム酸イオンの分析がより簡便に行える.

又，感度の低いところはプレカラム濃縮 法9)によるな ど，試料前処理の工夫により改良すれば，更に用途が拡 大されるものと考学られる。

終わりに，本研究を行うに当たり実験に協力いただい た滝 守氏に感謝する. $\left(\begin{array}{l}1977 \text { 年 } 10 \text { 月 } 13 \text { 日，日本分析化 } \\ \text { 学会第 } 26 \text { 年会において一部発表 }\end{array}\right)$

\section{交献}

1) JIS K 0101 (1971).

2) 丹野和夫 : 工化, 67, 895 (1964).

3) F. Pottkamp, F. Umland : Z. Anal. Chem., 255, 367 (1971).

4) 永長幸雄, 桜 幸子, 藤永太一郎: 日本分析化学 会第 23 年会講演要旨集, p. B 221 (1974).

5) J. D. H. Strickland : J. Amer. Chem. Soc., 74, 872 (1952).

6) W. D. Treadwell, Y. Schaeppi : Helv. Chim. Acta, 29, 771 (1946).

7) JIS K 0101 (1960). 解説.

8) "Treatise on Analytical Chemistry", Edited by I. M. Kolthoff, P. J. Elving, Part II, Vol. 2, p. 166 (1962), (Interscience Publishers Inc., New York).

9）高田芳矩, 宮城宏行, 広田邦男, 有川喜次郎: 本 誌，26; 752 (1977).

לs

Liquid-chromatographic determination of silicate, phosphate and germanate ions with coulometric detection. (Application of controlled potential coulometry to the automatic recording of 
liquid chromatography. IX.) Yoshinori TAKata* and Giichi Muto** (*Hitachi Research Laboratory, Hitachi, Ltd., 4026, Oomika, Kuji-machi, Hitachishi, Ibaraki; **Institute of Industrial Science, University of Tokyo, 7-22-1, Roppongi, Minato-ku, Tokyo)

A method for the coulometric detection of silicate, phosphate, and germanate ions with the molybdoheteropoly acids after the separation with anionexchange chromatography was investigated. The size of the separation column used was $9 \mathrm{~mm}$ in inside diameter and $80 \mathrm{~mm}$ in length, and strong base anion exchange resin was packed in the column. Good results was obtained when $0.4 \mathrm{M} \mathrm{NaOH}$ was used as the eluent for the separation of silicate and germanate ions, and $0.4 \mathrm{M} \mathrm{NaOH}-0.02 \mathrm{M} \mathrm{Na}_{2} \mathrm{SO}_{4}$ for silicate and phosphate ions. The optimum conditions for the coulometric detection of these ions are the following : the working electrode potential kept at $0.10 \mathrm{~V}$ vs. ferri-ferrocyanide, $\mathrm{H}_{2} \mathrm{SO}_{4}$ concentration in $(0.4 \pm 0.1) \mathrm{N}$, and reaction time for $5 \mathrm{~min}$ at $40^{\circ} \mathrm{C}$. The detection limit was $0.2 \mathrm{ppm}(0.1 \mu \mathrm{g}$, as $\mathrm{Si}$ and P) for silicate and phosphate ions. The linear dy- namic range was $(0.2 \sim 250) \mathrm{ppm}$ (as $\mathrm{P}$ ) for phosphate and $(0.2 \sim 50) \mathrm{ppm}$ (as Si) for silicate. And the coefficient of variation at $50 \mathrm{ppm}\{c a .200 \mathrm{ppm}$ (as Ge) for germanate $\}$ was less than $2 \%$ for these three ions. Alkaline earth and heavy metal ions more than $1000 \mathrm{ppm}$ interfered the determination because of their co-precipitation. Ions of $\mathrm{As}(\mathrm{V}), \mathrm{Sb}(\mathrm{V})$ and $\mathrm{Cr}(\mathrm{VI})$, however, did not interfere the detection. The method is useful for the determination of $\mathrm{ppm}$ level of these ions in water.

(Received May 4, 1978)

\section{Keywords}

Coulometry

Germanate ion

Ion-exchange chromatography

Molybdoheteropoly acid

Phosphate ion

Silicate ion

\title{
フェノール溶解法による高純度金属マグネシウム中の 酸化マグネシウムの定量
}

\author{
松 本 健 ${ }^{\circledR}$, 小泉 貞之，木羽 敏泰* \\ (1978 年 6 月 14 日受理)
}

\begin{abstract}
$100 \mathrm{ml}$ 二ロフラスコにフェノール $40 \mathrm{ml}$ を入れ, 予備加熱して脱水してからフラスコ内を窒素ふん い気とした後, 試料の高純度マグネシウム片を加え, 加熱還流すると, 金属はマグネシウムフェノオキ シドとなって溶解し, 酸化物は溶けないで残さとなる. 無水メタノールを加えて希釈後, 酸化物残さを 沪別し希塩酸で溶解した水溶液について，マグネシウムの量を原子吸光法で定量し酸化物量を求める. 本法の精度は高く，金属表面及び内部の酸化物の総量を簡単迅速に定量できる。
\end{abstract}

\section{1 緒 $\overrightarrow{\overrightarrow{1}}$}

金属マグネシウムは空気中で酸化されやすいため，漓 純度の品位の金属であっても精鍊工程や保存中に拈い て，生成した酸化マグネシウムを金属の内部や表面に含 有している．この微量の酸化マグネシウムは金属マグネ シウムの諸性質に影響を与えるので，高純度金属マグネ シウム中の酸化マグネシウムを簡単迅速に, かつ正確に **金沢大学理学部化学教室: 石川県金沢市丸の内 1-1
定量することは望まれるところである。マグネシウムと 酸化マグネシウムはともに各種試薬に対する化学的性質 が類似していること，及び含まれる酸化マグネシウムが 微量であることから，他金属に適用される酸溶解水素発 生法や臭素-メタノール法は適用乙難く, 又真空昇華法1) も不適である．既に両者のク口ム酸に対する溶解性の差 を利用した方法2) 4)が報告されているが，金属マグネシ ウムが水に溶解することを考慮すると，水溶液系を用い るのは好ましくない，又，著者らが先に高純度カドミウ 